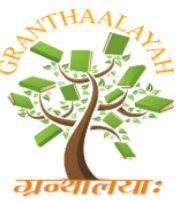

INTERNATIONAL JOURNAL OF RESEARCH GRANTHAALAYAH A knowledge Repository

Science

\title{
COLLEMBOLA DIVERSITY IN THE SOIL OF THE THREE TYPES OF LAND USED ON BUNGO DISTRICT JAMBI PROVINCE, INDONESIA
}

\author{
Febriyansyah *1 \\ ${ }^{* 1}$ Department of Biology, Faculty of Mathematics and Natural Sciences, Andalas University, \\ 25163 West Sumatra, Indonesia
}

DOI: https://doi.org/10.29121/granthaalayah.v5.i1.2017.1910

\section{Abstract}

The research regarding Collembola on Bungo District was conducted from February to July 2014. The purpose of this study was to know Collembola Diversity in the soil of the three types of land used (secondary forest, rubber plantation and palm plantation). This study used a purposive sampling method with soil drill having $4 \mathrm{~cm}$ diameter. The highest diversity on three types of land use is on rubber plantation and the lowest is on secondary forest. Family Entomobryidae (Ascocyrtus sp.) has the highest number of species as well as the highest percentage of all species.

Keywords: Bungo District; Collembola; Diversity; Jambi Province; Land Used; Soil.

Cite This Article: Febriyansyah. (2017). "COLLEMBOLA DIVERSITY IN THE SOIL OF THE THREE TYPES OF LAND USED ON BUNGO DISTRICT JAMBI PROVINCE, INDONESIA." International Journal of Research - Granthaalayah, 5(1), 362-367. https://doi.org/10.29121/granthaalayah.v5.i1.2017.1910.

\section{Introduction}

Soil is the living place for soil organisms. Soil organisms are indicator organism for good soil using decomposition process and energy flow. One of it is Collembola. Collembola are one of the soil organism also called Springtail ${ }^{[1]}$. Class of Collembola divided into 4 orders, which are Enthomobryomopha, Poduromorpha, Symphypleona, and Neelipleona ${ }^{[9]}$.

Collembola have body size around $200 \mu \mathrm{m}$ to $10 \mathrm{~mm}^{[10]}$. Collembola have different functions such as decomposition of soil organic compound and natural indicator ${ }^{[3]}$, as a decomposer of toxic compound and keeping the natural dynamic ecosystem ${ }^{[9]}$. On the other hand, Collembola also used for disease controller on some plants, example: Protaphorura armata has function of controlling diseases on the root of wheat plant that are infected by Fusarium culmorum and Gaeumannomyces graminis var tritici ${ }^{[8]}$. 
The presence of Collembola has width range in different areas. One of it is Bungo district. Bungo district is an area where land rapidly change, for example, secondary forest change with rubber plantation and oil palm plantation. This is located in Jambi Province, Indonesia. Beacuse there is less information about Collembola in this area, this study is conducted with aim to know diversity of Collembola on soil at three different types of land used and which factor had significant effect to diversity of Collembola in this area.

\section{Materials and Methods}

This study has been conducted between February to July 2014 on the three types of land used (Secondary Forest, Rubber Plantation and Palm Oil Plantation) in Bungo District, Jambi Province, Indonesia (Figure 1).

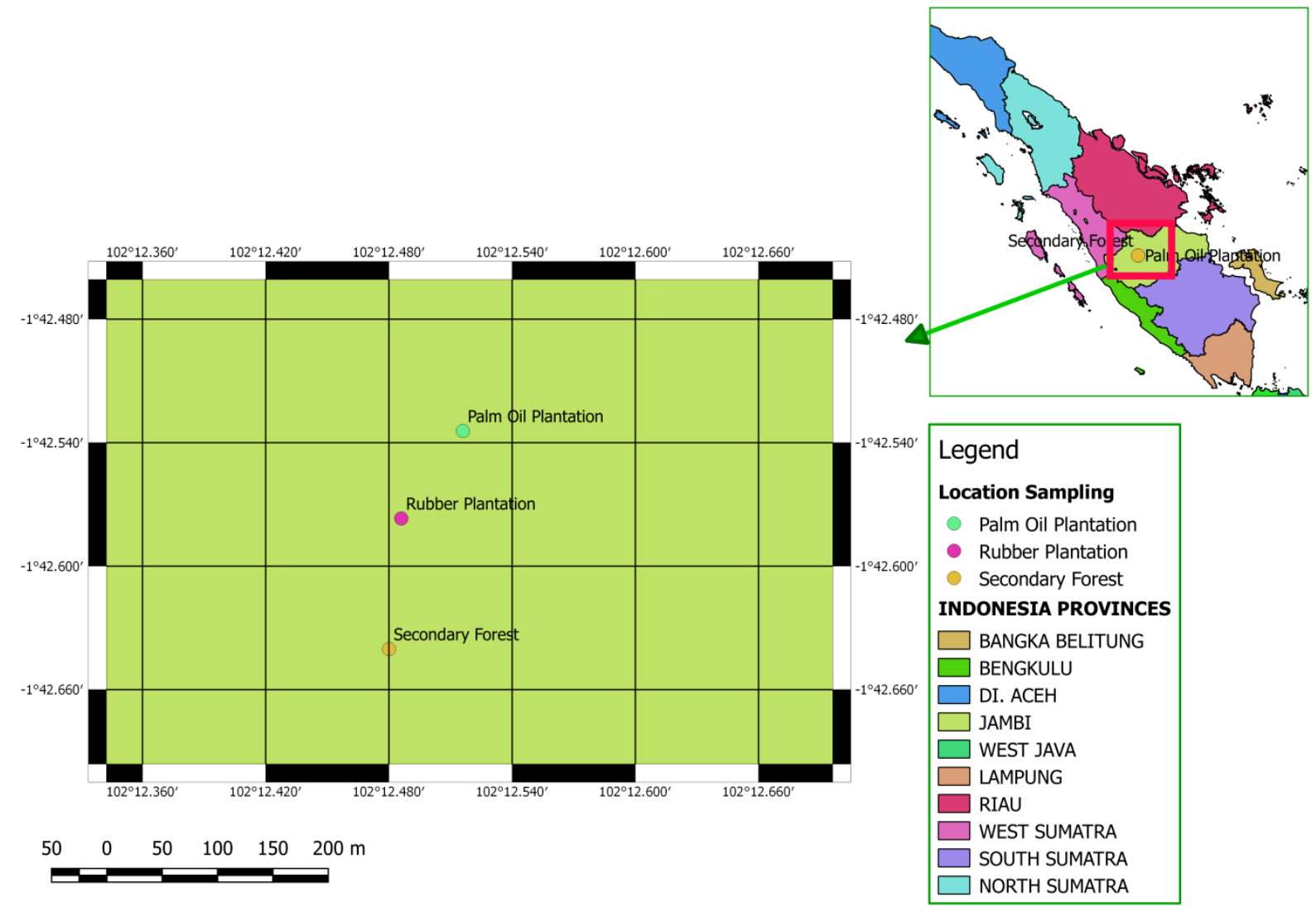

Figure 1: Map location of the study three types of land. a: Secondary forests; b. Rubber plantation; c. Oil Palm plantations. (Reference: Google, 17/101/2016 and Google map 17/01/2016).

In each land was taken 6 point of sampling, there are 2 point at first border, 2 point at the middle and the others at the second border. Each point was repeated 3 times (Figure 2). In this study, it is using soil drill with diameter $4 \mathrm{~cm}$. Then, the sample was get into plastic bag and named. After that, the samples were taken to laboratorium for extraction use Barlese Tullgreen methods for 72 hours and preserved it using alcohol 70\%. Identification sample of Collembola at Laboratorium 
of Animal Ecology, Biology Department, Faculty of Mathematic and Natural Sciences, Andalas University and also on Laboratorium of Zoology Indonesian Sciences Institutes, Cibinong, West Java Indonesia.

\section{Results and Discussions}

Table 1: Numbers of Family and Species of Collembola found on soil sample using soil drill.

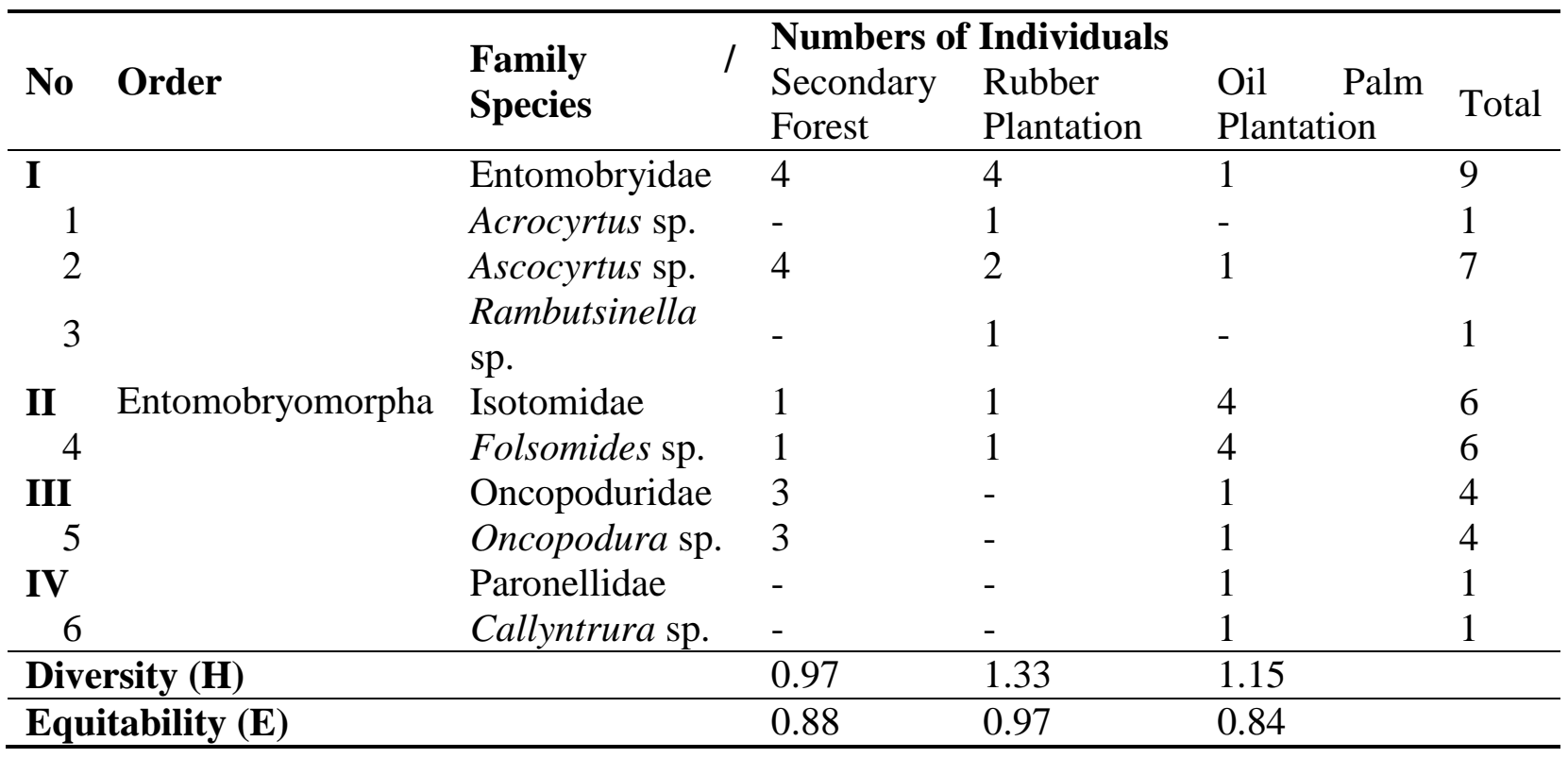

Collembola found around 20 individualss with 1 order that consist of 4 families and 6 species. On the three types of land used, generally, species with highest number is Ascocyrtus sp., (7 individuals) and Acrocyrtus sp., Rambutsinella sp., Callyntrura sp., (each 1 individuals) are the lowest species in the Bungo District.

Per three land, in the secondary forest got Collembola total 8 individualss with 3 species that belong to 3 families with diversity value 0.97 (low) also equitability 0.88 (almost similar). Ascocyrtus sp., is the most abundant species that found in this study with 4 individuals and the lowest species is Folsomides sp., (1 individuals).

Next, on the rubber plantation found Collembola with totals 5 individuals with 4 species that belong into 2 families and diversity value 1.33 (middle) also equitability 0.97 (similar). The highest species is Ascocyrtus sp., with 2 individuals. Acrocyrtus sp., Rambutsinella sp., and Folsomides sp. are the lowest Collembola with 1 individual each.

Furthermore, on the oil palm plantation found total Collembola 7 individuals with 4 species belong to 4 families with diversity value 1.15 belong to medium level and equitability 0.84 is enough similar level. Folsomides sp., is the highest number of individuals in oil palm plantation with 4 individuals and species with the lowest number of individuals are Ascocyrtus sp., Oncopodura sp., and Callyntrura sp., (each 1 individual). 


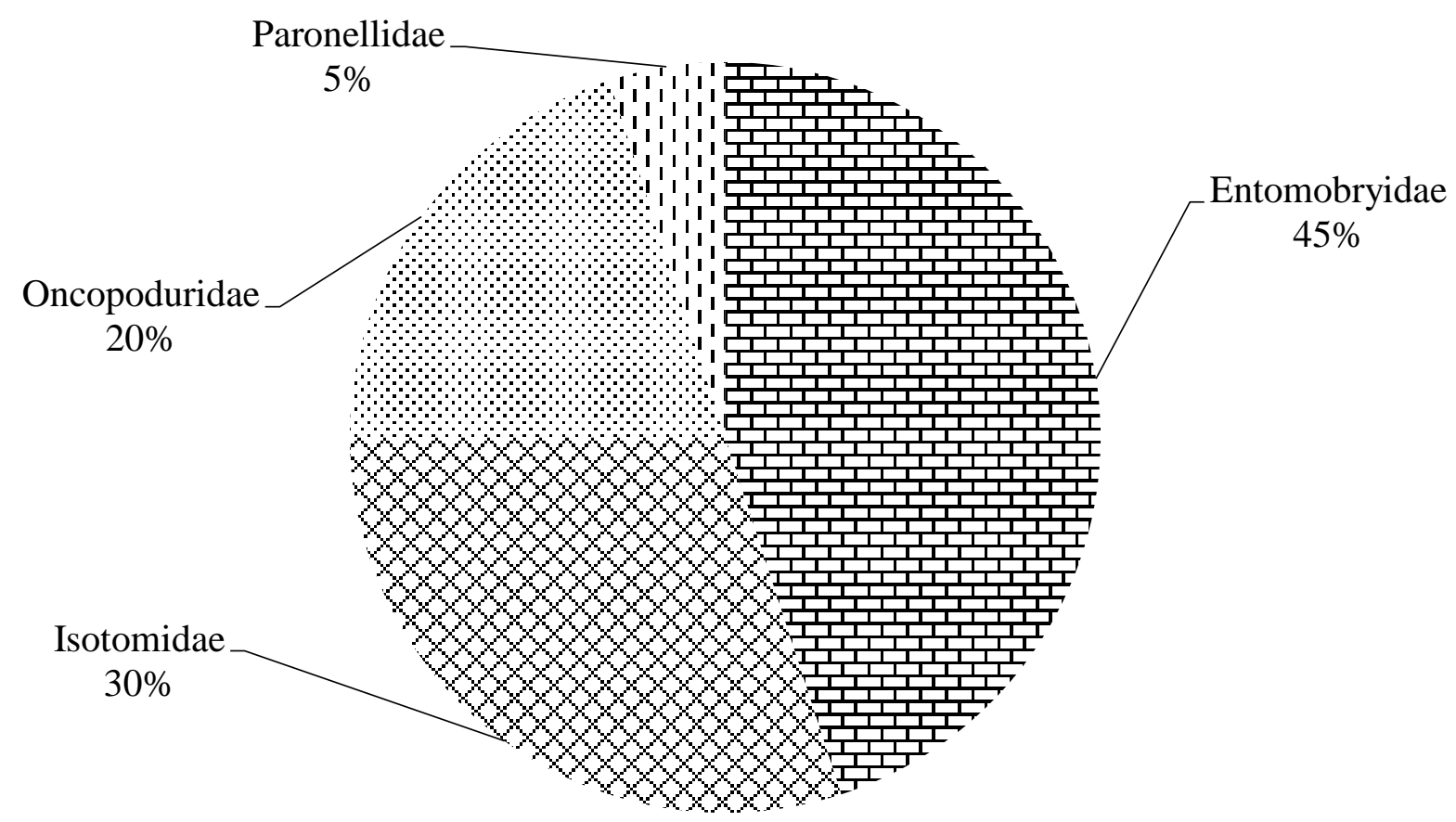

Figure 3: Percentage of Family of Collembola in three types of land used

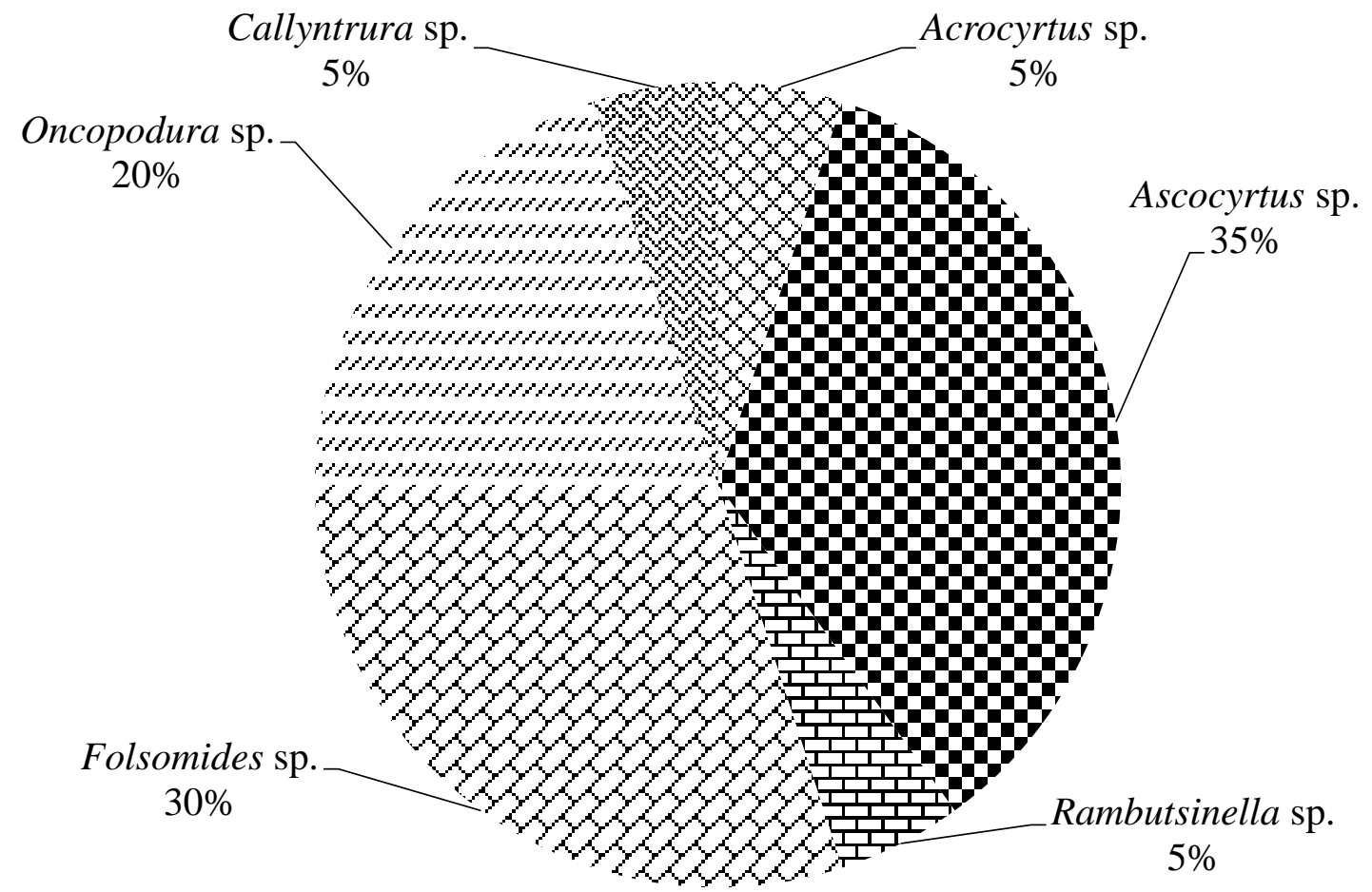

Figure 4: Percentage species of Collembola in the three types of land used 
The both figures showed that family Entomobryidae (45\%) is with the highest percentage and the lowest percentage is of family Paronellidae (5\%). Then, species that has highest percentage is Ascocyrtus sp., (35\%) and the lowest is Acrocyrtus sp., Callyntrura sp., and Rambutsinella sp. (each 5\%).

Some factors affected high and low numbers of individuals and species of Collembola, one of it is Levels of $\mathrm{C}$ organic. These were food source for Collembola. Levels of $\mathrm{C}$ organic in these studied around 1.29-1.63\%. This level belongs to low level condition if it is compared with Widyawati (2008) with 4.55-16.14 \%. But on Widyawati (2008) showed that with high level of $\mathrm{C}$ organic have high number of species and individuals. It is showed the more increasing levels $\mathrm{C}$ organic also increasing numbers of species and individuals found. ${ }^{(4)}$ states that Collembola is very sensitive with the presence or absence of food source in its habitat. In short, no food source no Collembola.

Diversity of Collembola in three types of land used at Bungo District belong to middle level. But if it compared each other's, the highest diversity found on rubber plantation (1.33) and the lowest diversity is secondary forest (0.97). But, according to t-test with confidence level $95 \%$, all the land got not significant different. Value of Collembola diversity found low because Levels of $\mathrm{C}$ organic is low. Low levels of $\mathrm{C}$ organic will make low numbers of species and individuals of Collembola. The high and low of diversity value affected by numbers of species and individuals [7].

The most found species was Ascocyrtus sp. It is because this areas are perfect match for this species. Species Ascocyrtus sp., always found on the different topography. ${ }^{[9]}$ states species Ascocyrtus sp., is a species that can be capable to adapting itself on the different extreme condition and topography. Collembola also sensitive with enviromental changes ${ }^{[5]}$.

Species of Folsomides sp., is a species that has high numbers of individuals at oil palm plantation. It is because this is the best place for it to live. Furthermore, Folsomides sp. live as cosmopolitan in litter habitat and soil. In Suhardjono et al. (2012) states Folsomides sp., can be found in litter and soil of in the middle of decomposition processing.

The presence or absence Collembola in one place affect by condition of habitat but also the present of their predator. ${ }^{[9]}$ states the present of Collembola affect by the present of their predator, habitat condition and topography area. The predator of Collembola likes Acarina, Coleoptera larvae, ant and spiders.

According to ${ }^{[6]}$ reported in Bangka island found 3 families of Collembola and ${ }^{[2]}$ found on the vermikoposting habitat with 2 families of Collembola. But in this study found total 4 families and 6 species.

\section{Conclusions and Recommendations}

In this study, it can take conclusion that diversity of Collembola got high in secondary forest but for more similarity of diversity species of Collembola is rubber plantation. In this study, found 1 order Entomobryopha with the highest number of individuals is Ascocyrtus sp., who belongs to 
family Entomobryidae. From this study, it can lead into another research such as the effect of ecological factors on one species of Collembola.

\section{Acknowledgments}

I would like to thank to Prof. Dr. Yayuk Rahayuningsih Suhardjono at the Zoological Laboratory-Indonesia Science Institute who has given me advised for identification sample of Collembola.

\section{References}

[1] Deharveng L, Suhardjono YR. Pseudosinella maros sp.n., a troglobitic Entomobryidae (Collembola) from Sulawesi Selatan, Indonesia. Journal Rev Suisse de Zoologie. 2004, 111: 979984.

[2] Ganjari EL. Species Richness of Collembola at Verkomposting Habitat. Jurnal of Universitas Katolik Widya Warta Madiun. 2012, 1, 0854-1981.

[3] Greenslade PL, Deharveng L, Bedos A, Suhardjono YR.. Handbook to Collembola of Indonesia. Cibinong. 2000, Fauna Malesiana (Draft final). 312

[4] Hopkin SP. Collembola. Encyclopedia of Soil Science. Maccel Dekker Inc, 2002, 207-210.

[5] Juceviva E, Melecis V. Long-term effect of climate warning on forest soil Collembola. Journal of Acta Zool Lituanica. 2005; 15: 124-126.

[6] Nurtjahya ED, Setiadi E, Guhardja, Muhadiono, Setiadi Y. Population of Collembola at the Revegetation Tailing land in Bangka Island. Journal of Biodiversitas. 2007.8 (4): 309-313.

[7] Odum EP. Fundamentals of Ecology. Third edition. Yogyakarta, 1998. Gadjah Mada University Press.

[8] Sabatini MA, Ventura M, Innocenti G. Do Collembola affect the competitive relationships among soil-borne plant pathogenic fungi. Pedobiologia. 2004. 48: 603-608.

[9] Suhardjono YR, Deharveng L, Bedos A. Collembola (Springtails). Vegamedia. Bogor, 2012.

[10] Wallwork JA. Ecology of Soil Animals. Mc Graw Hill. London, 1970. 283 p.

[11] Widyawati IT. Soil Surface Collembolan Communities of Five Habitats in Telaga Warna Area (Bogor and Cianjur Regency).[Thesis]. IPB Bogor. West Java, 2008. Unpublished.

*Corresponding author.

E-mail address: febriyansyah.ok87@gmail.com 